\title{
Respons Pertumbuhan dan Produksi Kedelai Varietas Wilis (Glycine max (L.) Merril.) Terhadap Aplikasi Asam Salisilat dan Kitosan
}

Growth and Production of Soybean (Glycine max (L.) Merril.) Wilis on the Salicylic Acid and Chitosan Application

\section{Rijalul afkar, Ferry Ezra T. Sitepu*, Yaya Hasanah}

Program Studi Agroteknologi, Fakultas Pertanian Universitas Sumatera Utara, Medan 20155

*Coressponding author : Ferryezrasitepu6@gmail.com

\section{ABSTRACT}

Soybean demand from year to year continues to increase according to (BPS). Data from centers and agricultural information states center shows that the necessity of domestic soybean in 2015 amounted to 2,35 million tons. There is still a supply shortfall of one million tons more. Therefore the offort to increase the productivity of soybean one of them is the application elicitor.The aim of this research to know the response to growth and production of soybean variety of wilis on elicitor application.The research was conducted at Pasar 1 Tanjung Sari, Kecamatan Medan Sunggal, Medan, in June, july, august 2017. This research used non factorial Randomized Block Design (RBD)which is without elicitor, Chitosan $0,5 \mathrm{mg} / \mathrm{ml}$ on V4,Chitosan 0,5 $\mathrm{mg} / \mathrm{ml}$ on R3, Salicylic acid 0,5mM on V4, Salicylic acid 0,5 $\mathrm{mM}$ on R3, Chitosan 0,5 $\mathrm{mg} / \mathrm{ml}$ on V4 and R3, Salicylic acid 0,5 $m M$ on V4 and R3. The parameters observed were plant height, total leaf area, number of pods containing and seeds dry weight of 100 .The results showed significant differences on plant height at 6 week after planting $(54,47 \mathrm{~cm})$ while on parameters total leaf area $\left(2454,00 \mathrm{~cm}^{2}\right)$, number of pods containing $(178,20 \mathrm{pod})$ and seeds dry weight of $100(10,47 \mathrm{~g})$ have no significant effect.

Keywords: elicitor, growth, production, soybean.

\section{ABSTRAK}

Kebutuhan kedelai dari tahun ke tahun terus mengalami peningkatan menurut (BPS). Data dari pusat data dan informasi pertanian menyebutkan bahwa kebutuhan konsumsi kedelai dalam negeri tahun 2015 sebanyak 2,35 juta ton. Masih terdapat kekurangan pasokan sebanyak satu juta ton. Usaha peningkatan produktivitas kedelai salah satunya yaitu pengaplikasian elisitor. Penelitian ini bertujuan untuk mengetahui respons pertumbuhan dan produksi kedelai varietas wilis terhadap aplikas ielisitor. Penelitian dilaksanakan di Pasar 1 Tanjung Sari, Kecamatan Medan Sunggal, Medan, pada bulan Juni-Agustus 2017. Penelitian ini menggunakan rancangan acak kelompok non faktorial yaitu: tanpa elisitor,Kitosan $0,5 \mathrm{mg} / \mathrm{ml}$ pada V4,Kitosan $0,5 \mathrm{mg} / \mathrm{ml}$ pada R3, Asam salisilat $0,5 \mathrm{mM}$ pada V4,Asam salisilat $0,5 \mathrm{mM}$ pada $\mathrm{R} 3$, Kitosan $0,5 \mathrm{mg} / \mathrm{ml}$ pada $\mathrm{V} 4$ dan $\mathrm{R} 3$,Asam salisilat $0,5 \mathrm{mM}$ pada V4 dan R3 . Paramater yang diamati adalah tinggi tanaman, jumlah daun, jumlah polong berisi dan bobotkering 100 biji. Hasil penelitian menunjukkan perbedaan yang nyata terhadap tinggi tanaman pada minggu ke $6(54,47 \mathrm{~cm})$, sedangkan pada parameter total luas daun $\left(2454,00 \mathrm{~cm}^{2}\right)$, jumlah polong berisi (178,20 polong) dan bobot kering 100 biji $(10,47 \mathrm{~g})$ berpengaruh tidak nyata.

Kata Kunci: elisitor, kedelai, pertumbuhan, produksi.

\section{PENDAHULUAN}

Kedelai sebagai bahan makanan mempunyai nilai gizi cukup tinggi karena merupakan sumber protein, lemak, vitamin, mineral dan serat paling baik. Kedelai mengandung beberapa fosfolipida penting dan menempati urutan pertama akan kandungan 
senyawa isoflavon dan derivatnya. Isoflavon adalah salah satu golongan dari kelompok flavonoida merupakan golongan senyawa metabolit sekunder yang banyak terdapat pada tumbuh-tumbuhan, khususnya Leguminoceae yang diketahui berfungsi sebagai antioksidan, antitumor, anti kanker dan anti ostero klerorosis. Dengan berbagai manfaat dan khasiatnya itu, sangat disayangkan sampai saat ini negara Kita masih belum dapat memenuhi sendiri kebutuhan akan kedelai (Atun, 2009).

Kebutuhan kedelai dari tahun ke tahun terus mengalami peningkatan. Menurut data Badan Pusat Statistik (BPS) produksi kedelai nasional tahun 2015 mencapai 963.183 ton biji kering naik 14,44 persen atau 70.583 ribu ton dibandingkan 2014 sebesar 892.600 ribu ton. Data dari Pusat Data dan Informasi Pertanian menyebutkan bahwa kebutuhan konsumsi kedelai dalam negeri tahun 2015 sebanyak 2,35 juta ton. Masih terdapat kekurangan pasokan sebanyak satu juta ton lebih (Badan Libang Pertanian,2014).

Usaha peningkatan produktivitas kedelai tidak terlepas dari berbagai kendala antara lain adanya gangguan hama penyakit. Ketahanan terhadap penyakit merupakan salah satu sifat yang sangat penting karena mempengaruhi kualitas dan tingkat produksi tanaman. Salah satu alternatif upaya peningkatan kuantitas dan kualitas produk pertanian khususnya kedelai dapat dilakukan dengan pemanfaatan agen hayati (biopestisida) melalui induksi ketahanan sistemik dengan peningkatan metabolit sekunder yang dipicu oleh pengaplikasian elisitor tertentu (Hoerussalem et al. 2013).

Pertumbuhan tanaman kedelai dibagi dalam dua fase (stadia) yakni fase vegetatif dan fase generatif (reproduktif). Fase vegetatif dilambangkan dengan huruf $\mathrm{V}$, sebaliknya fase generatif atau reproduktif dengan huruf R. Fase vegetatif dimulai sejak tanaman tumbuh dan umumnya dicirikan oleh banyaknya buku pada batang utama yang telah memiliki daun terbuka penuh dan fase vegetatif berakhir manakala telah terbentuk satu bunga pada batang utama, dengan demikian fase generatif dimulai oleh terbentuknya satu bunga dan diakhiri oleh jika tanaman telah $95 \%$ polongnya telah matang (Adie dan Krisnawati, 2006).

Elisitor merupakan senyawa biologis maupun non biologis yang diinduksi dan menyebabkan fitoaleksin diproduksi. Metode elisitasi dapat dilakukan dengan menambahkan elisitor abiotik maupun biotik pada sel tumbuhan dengan tujuan untuk menginduksi secara simultan fitoaleksin dan metabolit sekunder konstitutif atau metabolit sekunder lain yang secara normal tidak terakumulasi. Elisitasi juga merupakan suatu respons dari suatu sel untuk menghasilkan metabolit sekunder. Dalam hal ini, adanya interaksi patogen dengan inang akan menginduksi pembentukan fitoaleksin pada tumbuhan. Fitoaleksin itu sendiri merupakan senyawa antibiotik yang mempunyai berat molekul rendah, dan dibentuk sebagai respons terhadap infeksi mikroba patogen. Senyawa yang merupakan bagian dari mekanisme tersebut dapat dianalogikan dengan antibodi yang terbentuk sebagai respons imun (Al-Tawaha et al. 2005).

Elisitor terdiri atas dua kelompok yaitu elisitor abiotik dan biotik (Al-Tawaha, 2011). Elisitor biotik dikelompokkan dalam elisitor endogen dan eksogen. Elisitor endogen umumnya berasal dari tumbuhan itu sendiri, seperti bagian dari dinding sel (oligogalakturonat) yang rusak oleh suatu serangan patogen melalui aktivitas enzim hidrolisis atau membran plasma yang mengalami kerusakan karena luka. Sedangkan elisitor eksogen berasal adalah elisitor yang berasal dari luar tumbuhan atau luar sel, misalnya elisitor yang berasal dari dinding sel jamur. Elisitor abiotik yang sering digunakan yaitu metil jasmonat dan asam salisilat, sedangkan elisitor biotik misalnya kitosan (Namdeo, 2007).

Asam salisilat memegang peranan penting dalam ketahanan sistemik terinduksi. Asam salisilat di gunakan pada tanaman sebagai reaksi terhadap infeksi patogen, dan digunakan sebagai racun murni pada penyakit layu Fusarium. Mekanisme ketahanan 
tanaman terhadap penyakit dapat berupa ketahanan secara fisik maupun kimia. Salah satu bentuk ketahanan secara kimia adalah asam salisilat. Asam salisilat lebih dominan untuk mengatasi serangan patogen biotrof (patogen yang aktif pada jaringan hidup) dan virus. Mekanisme ketahanan melalui jalur asam salisilat berhubungan dengan proteinprotein yang terkait dengan pathogenesis (Sulastri, 2014).

Kitosan terbukti menghambat penyebaran sistemik virus dan viroid seluruh tanaman dan untuk meningkatkan respon hipersensitif host terhadap infeksi. Kitosan menghambat pertumbuhan dan perkembangan Escherichia Coli terutama di media asam. Secara umum kitosan diterapkan pada tingkat $1 \mathrm{mg} / \mathrm{mL}$, mampu mengurangi pertumbuhan vitro sejumlah jamur dan Oomycetes. Substratum perubahan dengan kitosan diketahui untuk meningkatkan pertumbuhan tanaman dan menekan beberapa penyakit patogen tular tanah terkenal (Sugeno, 2008). Hirano et al (2000) juga menyatakan bahwa terjadi peningkatan hasil biji kedelai sebesar $20 \%$ dengan perlakuan Kitosan 1mg/mL.

\section{BAHAN DAN METODE}

Penelitian di laksanakan di Pasar 1 Tanjung Sari, Kecamatan Medan Sunggal, Medan, dengan ketinggian tempat \pm 25 meter di atas permukaan laut, dimulai pada bulan Juni 2017 sampai dengan selesai.

Bahan yang digunakan adalah benih kedelai varietas Wilis sebagai objek yang akan ditanam dan diamati, top soil sebagai media tanam, label sebagai penanda, pupuk Urea TSP dan $\mathrm{KCl}$ untuk pemupukan dasar, elisitor (asam salisilat $(0,5 \mathrm{mM})$, kitosan $(0,5$ $\mathrm{mg} / \mathrm{ml})$ ) sebagai perlakuan yang akan diaplikasikan pada tanaman kedelai, aquades sebagai pelarut elisitor, air untuk menyiram tanaman dan bahan-bahan lain yang mendukung penelitian ini.

Alat yang digunakan yaitu cangkul untuk membersihkan gulma pada lahan, meteran untuk mengukur, alat-alat laboratorium untuk membuat larutan elisitor, handsprayer untuk mengaplikasikan elisitor, gembor untuk menyiram, gunting untuk memotong, timbangan analitik untuk menimbang pupuk dasar, serta alat pendukung lainnya.

Penelitian menggunakan rancangan acak kelompok (RAK) non faktorial yaitu : $\mathrm{E}_{0}$ : Tanpa Elisitor, $\mathrm{E}_{1}$ : Kitosan $(0,5 \mathrm{mg} / \mathrm{ml})$ pada $\mathrm{V} 4, \mathrm{E}_{2}$ : Kitosan $(0,5 \mathrm{mg} / \mathrm{ml})$ pada $\mathrm{R} 3$ $\mathrm{E}_{3}$ : Asam salisilat $(0,5 \mathrm{mM})$ pada $\mathrm{V} 4, \mathrm{E}_{4}$ : Asam salisilat $(0,5 \mathrm{mM})$ pada $\mathrm{R} 3, \mathrm{E}_{5}$ : Kitosan $(0,5 \mathrm{mg} / \mathrm{ml})$ pada V4 dan $\mathrm{R} 3, \mathrm{E}_{6}$ : Asam salisilat $(0,5 \mathrm{mM})$ pada V4 dan R3

Pelaksanaan penelitian ini meliputi persiapan lahan, persiapan benih, penanaman, pemupukan dasar, pengaplikasian elisitor, pemeliharaan tanaman, penyiraman, penjarangan, penyulaman, penyiangan, pengendalian HPT (hama dan penyakit tanaman) dan panen.

Peubah amatan penelitian ini yaitu: tinggi tanaman, jumlah daun, total luas daun, rasio tajuk akar, jumlah polong berisi, jumlah polong hampa, bobot kering biji pertanaman dan bobot kering 100 biji.

\section{HASIL DAN PEMBAHASAN}

Berdasarkan hasil sidik ragam diketahui bahwa perlakuan jenis elisitor berpengaruh tidak nyata terhadap tinggi tanaman, jumlah daun, bobot kering biji, jumlah polong berisi, jumlah polong hampa dan bobot 100 biji. 
Tabel 1. Tinggi tanaman kedelai dengan perlakuan jenis elisitor

\begin{tabular}{|c|c|c|c|c|}
\hline \multirow{2}{*}{ Perlakuan } & \multicolumn{4}{|c|}{ Tinggi Tanaman } \\
\hline & $3 \mathrm{MST}$ & $4 \mathrm{MST}$ & $5 \mathrm{MST}$ & $6 \mathrm{MST}$ \\
\hline & & ........cm & & \\
\hline E0 (Tanpa Elisitor) & $12,66 b c$ & $25,77 \mathrm{a}$ & $34,85 \mathrm{a}$ & $52,20 \mathrm{a}$ \\
\hline E1 (Kitosan, V4) & $12,14 \mathrm{c}$ & $20,95 b$ & $29,80 \mathrm{~b}$ & $44,07 \mathrm{~b}$ \\
\hline E2 (Kitosan, R3) & $14,36 \mathrm{a}$ & $28,43 a$ & $38,00 \mathrm{a}$ & $54,47 \mathrm{a}$ \\
\hline E3 (Asam Salisilat, V4) & $14,06 a$ & $26,9 \mathrm{a}$ & $36,43 a$ & $53,00 \mathrm{a}$ \\
\hline E4 (Asam Salisilat, R3) & $12,87 b$ & $25,23 \mathrm{a}$ & $33,83 \mathrm{a}$ & $48,27 \mathrm{a}$ \\
\hline E5 (Kitosan, V4 dan R3) & $13,89 \mathrm{a}$ & $24,38 \mathrm{ab}$ & $34,60 \mathrm{a}$ & $48,73 \mathrm{a}$ \\
\hline E6 (Asam Salisilat, V4 dan R3) & $13,48 \mathrm{a}$ & $25,70 \mathrm{a}$ & $34,87 \mathrm{a}$ & $52,77 \mathrm{a}$ \\
\hline Rataan & 13,35 & 25,34 & 34,63 & 50,50 \\
\hline
\end{tabular}

Tinggi Tanaman

Berdasarkan Tabel 1 diketahui bahw Perlakuan asam salisilat dan kitosan berpengaruh tidak nyata terhadap tinggi tanaman, pada pengamatan tinggi tanaman 6 MST dapat diketahui bahwa tinggi tanaman pada perlakuan kitosan pada V4 (E1) $(44,07$ $\mathrm{cm})$ yang berbeda nyata dengan perlakuan E0, E2,E3, E4, E5, E6 dan pemberian kitosan (E1) pada umumnya lebih rendah dibanding perlakuan lainnya. Hal ini menunjukkan elisitor yang digunakan yaitu kitosan cenderung meghambat pertumbuhan vegetatif tanaman kedelai, sehingga berpengaruh terhadap produksi tanaman yang dihasilkan selain itu juga diduga bahwa elisitor tidak berada pada konsentrasi yang tepat. Apabila kitosan berada dalam jumlah yang berlebih atau kekurangan akan bersifat bukan sebagai pemicu melainkan menghambat pertumbuhan dan produksi tanaman. Hal ini sependapat dengan Eliwati (2014) yang menyatakan bahwa elisitor banyak berperan dalam tanaman, mulai dari faktor pertahanan, penuaan daun, dan regulator kematian sel, karna fungsinya dari elisitor yang digunakan termasuk kedalam hormon tumbuhan. Pengunaan elisitor dalam konsentrasi yang besar dapat menghambat pembelahan sel, namun dalam konsentrasi kecil justru dapat meningkatkan pembelahan sel. Hormon akan bersifat aktif dan khas apabila dalam jumlah yang cukup dalam sel yang tepat dan dikenali serta diikat kuat oleh sel target / sasaran. AlTawaha (2012) menyatakan bahwa faktor yang menentukan keberhasilan elisitasi diantaranya adalah jenis elisitor, konsentrasi elisitor dan waktu kontak antara sel dengan elisito

Tabel 2. Total luas daun dan rasio tajuk akar kedelai dengan perlakuan jenis elisitor.

\begin{tabular}{lc}
\hline \multicolumn{1}{c}{ Perlakuan } & Total Luas Daun $\left(\mathrm{cm}^{2}\right)$ \\
\hline E0 (Tanpa Elisitor) & 1228,67 \\
E1(Kitosan, V4) & 614,64 \\
E2 (Kitosan, R3) & 2229,12 \\
E3 (Asam Salisilat, V4) & 1635,89 \\
E4 (Asam Salisilat, R3) & 2454 \\
E5 (Kitosan, V4 dan R3) & 2413,36 \\
E6 (Asam Salisilat, V4 dan R3) & 1337,51 \\
\hline Rataan & 1701,89 \\
\hline
\end{tabular}


Tabel 3. Jumlah polong berisi dan jumlah polong hampa dengan perlakuan jenis elisitor

\begin{tabular}{|c|c|}
\hline Perlakuan & Jumlah polong berisi (Polong) \\
\hline E0(Tanpa Elisitor) & 178,20 \\
\hline E1(Kitosan, V4) & 177,40 \\
\hline E2(Kitosan, R3) & 159,80 \\
\hline E3(Asam Salisilat, V4) & 119,00 \\
\hline E4(Asam Salisilat, R3) & 117,67 \\
\hline E5(Kitosan, V4 dan R3) & 126,60 \\
\hline E6(Asam Salisilat, V4 dan R3) & 166,27 \\
\hline Rataan & 149,28 \\
\hline
\end{tabular}

Tabel 4. Bobot kering biji per tanaman dan bobot kering 100 biji kedelai dengan perlakuan jenis elisitor.

\begin{tabular}{|c|c|}
\hline Perlakuan & Bobot Kering 100 Biji (g) \\
\hline E0 (Tanpa Elisitor) & 9,54 \\
\hline E1(Kitosan, V4) & 10,03 \\
\hline E2 (Kitosan, R3) & 10,47 \\
\hline E3 (Asam Salisilat, V4) & 9,89 \\
\hline E4 (Asam Salisilat, R3) & 9,81 \\
\hline E5 (Kitosan, V4 dan R3) & 9,18 \\
\hline E6 (Asam Salisilat, V4 dan R3) & 10 \\
\hline Rataan & 9,85 \\
\hline
\end{tabular}

\section{Total Luas Daun}

Berdasarkan Tabel 2 pada perlakuan elisitor Asam Salisilat pada R3 (E4) menghasilkan total luas daun yang cenderung lebih tinggi yaitu $2454,00 \mathrm{~cm}^{2}$, dan terendah pada jenis elisitor Kitosan pada V4 (E1) yaitu $614,64 \mathrm{~cm}^{2}$. Hal ini dikarenakan konsentrasi kitosan yang diberikan kurang optimal dalam meningkatkan produksi jumlah cabang tanaman kedelai. Kitosan memiliki gugus $\mathrm{N}$ yang reaktif dan sifat hidrophillic. Gugus $\mathrm{N}$ yang ada pada kitosan mampu meningkatkan kinerja unsur $\mathrm{N}$ yang ada di dalam tanah dan sifat hidrophillic kitosan membantu proses penyerapan air yang ada di tanah. Air dan unsur $\mathrm{N}$ yang ada pada tanah merupakan faktor luar yang dapat mempercepat pertumbuhan tanaman secara efektif apabila terpenuhi, apabila kekurangan unsur $\mathrm{N}$ dan air akan memperlambat pertumbuhan cabang tanaman.. Hal ini juga diduga karena jenis elisitor yang digunakan tidak responsif terhadap waktu apliaksi yang digunakan, demikian juga sebaliknya. Dengan kata lain, penggunaan jenis elisitor dan waktu aplikasi elisitor menjalankan fungsinya masingmasing tanpa membentuk suatu hubungan atau sinergi dalam meningkatkan produksi kedelai. Hal ini sependapat dengan A-tawaha et al. (2006) yang menyatakan bahwa pada fase V4 dan R3 elisitor mulai bekerja, dengan adanya perlakuan elisitor dan di aplikasikan pada fase tersebut.

\section{Jumlah Polong Berisi dan Bobot kering 100 biji}

Berdasarkan Tabel 3. Dapat diketahui bahwa perlakuan tanpa elisitor (E0) menghasilkan jumlah polong berisi yang cenderung lebih tinggi yaitu 178,20 polong, dan terendah pada jenis elisitor Asam Salisilat pada R3 (E4) yaitu 117,67 polong. Berdasarkan Tabel 4 pada perlakuan jenis elisitor Kitosan pada R3 (E2) menghasilkan bobot kering 100 biji yang cenderung lebih tinggi yaitu 10,47 g, dan terendah pada jenis elisitor Kitosan pada V4 dan R3 (E5) yaitu 9,18 g .Hal ini diduga karena kurangnya konsentrasi pemberian kitosan pada saat 
pengaplikasian, hal ini sependapat dengan Uthairatanakij et al. (2007) menyatakan bahwa kitosan dapat meningkatkan sinyal untuk sintesis hormon tanaman seperti giberelin dalam jumlah yang optimal, apabila berlebihan akan menghambat pertumbuhan kedelai. Sifat hidrophillic kitosan menyebabkan kitosan mampu menyerap air dari lingkungan dan penyerapan air dari lingkungan akan masuk ke dalam biji, bila berlebihan akan menyebabkan biji dorman kembali (Gardner et al. 1991). Kembalinya biji menjadi dorman akan menyebabkan biji tersebut busuk di dalam tanah.

\section{SIMPULAN}

Perlakuan kitosan dan asam salisilat menunjukkan pengaruh nyata terhadap pengamatan tinggi tanaman tertinggi pada 3 MST yakni $14,36 \mathrm{~cm}$, pada 4 MST yakni $28,43 \mathrm{~cm}$, pada 5 MST yakni $38,00 \mathrm{~cm}$ dan pada 6 MST yakni $54,47 \mathrm{~cm}$. Perlakuan yang terbaik untuk produksi terdapat pada kitosan R3 dimana pada fase ini elisitor mulai aktif untuk bekerja.

\section{DAFTAR PUSTAKA}

Adie, M.M dan A. Krisnawati. 2007. Peluang peningkatan kualitas biji kedelai. Prosiding. Risalah Seminar. 23 November 2008. Badan Litbang Pertanian. pp.216-230.

Al-Tawaha, A. M., Seguin, P., Smith, D. L. and Beaulieu, C. 2005. Biotic elicitors as a means of increasing isoflavone concentration of soybean seeds. Ann. Appl. Biol. 146: 303310.

Al-Tawaha, A.R.M . 2006. Factors Affecting Isoflavone Concentration in Soybean

(Glycine $\max$ L.). Thesis. Mc Gill University, Macdonald Campus SteAnne-de-Bellevue, QC, Canada.

Al-Tawaha, A.R.M dan Ababneh, F. 2011. Effects of Site and Exogenous Application of Yeast Extract on the Growth and Chemical Composition of Soybean. International Conference on Agricultural, Environment and Biological Sciences (ICAEBS'2012), Phuket.

Atun, S. 2009. Potensi Senyawa isoflavon dan Derivatnya dari Kedelai (Glycine max L.) Serta Manfaatnya Untuk Kesehatan. Prosiding Seminar Nasional Penelitian, Pendidikan dan Penerapan MIPA, Fakultas MIPA, Universitas Negeri Yogyakarta, 16 Mei 2009.

Badan Litbang Pertanian. 2014. Kedelai. Dikutip dari http://www. sumut. litbang. deptan.go.id. Diakses pada Tanggal 2 Maret 20115.

Badan Pusat Statistik. 2015. Data Produksi Tanaman Jagung, Padi dan Kedelai. Sumatera Utara. Medan.

Eliwati, S. 2014. Metabolit Pegagan. Tinjauan Pustaka Dikutip dari http://usurepository.ac.id. Diakses pada tanggal 18 Maret 2016.

Gardner FP, Pearce RB, and Mitchell RL.1991. Physiology of Crop Plants. Diterjemahkan oleh H.Susilo. Jakarta. Universitas Indonesia Press.

Hirano, S., M. Hayashi, S. Okuno. 2000. Soybean seeds surface-coated with depolymerised chitins: chitinase activity as a predictive index for the harvest of beans in field culture. Journal of the Science of Food and Agriculture 81:205-209.

Hoerussalem., A. Purwantoro dan A. Khaeruni. 2013. Induksi Ketahanan Tanaman Kedelai Terhadap Penyakit Bulai Melalui Seed Treatment Serta Pewarisannya Pada Generasi S1. Ilmu Pertanian Vol. 16 (2):42 - 59.

Namdeo A. G. 2007. Plant Cell Elicitation for Production of Secondary Metabolites. Pharmacognosy Reviews Vol 1, Issue 1.

Sugeno, R, 2008. Budidaya Kedelai. http://warintek.ristek.go.id/pertanian/ kedelai.pdf. 2008. diakses pada tanggal 15 Januari 2016. 
Sulastri, S. 2014. Bab I. Dikutip dari http://unsri.ac.id. Diakses pada tanggal 24 Maret 2016.

Uthairatanakij A, Silva JAT, Obsuwan K. 2007. Chitosan for improving orchid production and quality. J. Orchid Sci and Biotech. $1: 1-5$ 